Article

\title{
Earnings Management and CSR Disclosure. Family vs. Non-Family Firms
}

\author{
Giovanna Gavana $^{1}$ (D), Pietro Gottardo ${ }^{2}$ (D) and Anna Maria Moisello ${ }^{2, *}$ \\ 1 Department of Economics, University of Insubria, 21100 Varese, Italy; giovanna.gavana@uninsubria.it \\ 2 Department of Economics and Management, University of Pavia, 27100 Pavia, Italy; pietro.gottardo@unipv.it \\ * Correspondence: annamaria.moisello@unipv.it; Tel.: +39-382-986-247
}

Received: 9 November 2017; Accepted: 11 December 2017; Published: 13 December 2017

\begin{abstract}
Building on Institutional theory and Signaling theory, integrated with the socioemotional wealth (SEW) approach, we studied the effect of earnings management (EM) practices on a firm's Corporate Social Responsibility (CSR) disclosure behavior. In so doing, we analyzed a sample of 226 non-financial, family and non-family listed firms for the period, 2006-2015. Our results suggest that family firms, in instances of downward earnings management, are more prone to diverting attention from these practices by means of CSR disclosure, compared to non-family firms, although the level of family ownership exerts a moderating effect. Moreover, we found that a firm's visibility, in terms of size, significantly enhances this behavior and that the effect is higher for family firms.
\end{abstract}

Keywords: CSR disclosure; earnings management; family firms

\section{Introduction}

Literature is widely engaged in the interpretation of the motivations underlying a firm's involvement in corporate social responsibility (CSR) activities and voluntary CSR disclosure. According to Institutional theory, firms try to behave consistently with the values of society and of their salient stakeholders [1], in order to avoid legitimacy gaps [2] which may threaten their durability [3,4].

Companies may adopt different strategies for achieving, maintaining and repairing their legitimacy to operate [5]. They may provide information about decisions which are expected to improve their social and environmental performance [6], and they may also use CSR disclosure, in order to change the general public and stakeholders' perceptions related to the fairness of their behavior [7]. CSR disclosure commitment is a means of shaping a firm's public image and legitimacy [8], but it may also be used to divert attention from unethical practices through social performance communication. Accordingly, Chih et al. [9] point out examples of internationally-known large scale companies-i.e., Shell, Coca Cola and British American Tobacco-strongly committed to the disclosure of their CSR activities, while at the same time, not behaving in a socially responsible manner. Enron, a well-known case, was very active in publishing social and environmental reports on its responsible work, while it was engaging in false financial information. Literature suggests that as firms use CSR disclosure to hide unethical behaviors, companies, with low mandatory financial information quality, may use CSR reporting in order to mask their earnings management (EM) practices by means of a CSR information overload [10]. Different kinds of financial and non-financial voluntary disclosure may be used in order to give the impression of a transparent company and divert attention from unethical accounting practices. A company may choose to engage in CSR reporting, as it is an effective tool to strengthen a company's image [11], to manage reputational risk [12] and dampen a potential legitimacy gap. As a matter of fact, a firm's legitimacy depends both on its financial and CSR reputation-the mechanisms for perception creation are, respectively, financial and CSR reporting [12]. Consistently, Martinez-Ferrero et al. [13] argue that firms with poor financial reporting might use standardized 
social and environmental information as a tool of legitimacy, to compensate for the poor quality of financial information. Investors are interested in financial information, but they also positively value social and environmental information [14,15]; therefore, companies, involved in earnings management, might be more prone to providing CSR information in order to create a socially and environmentally responsible image, and lower the risk of a close monitoring of their financial statements. Given the relevant potential damage of earnings management (EM) practices for stakeholders [9], it is of interest to investigate in which circumstances CSR disclosure may be a way to mask the manipulation of accounting numbers. Extant literature provides evidence on how a firm's CSR behavior relates to its earnings management attitude. Findings suggest that earnings management leads to an increase in CSR activities and this effect is particularly evident for firms in industries or countries where stakeholder pressure is stronger [16]. A greater commitment to CSR activities signals that managers are trying to satisfy all of a firm's stakeholders, following a multiple-objectives strategy. This leads them to be less accountable in the use of the firm's resources and more prone to using resources for private benefit. Since this behavior would emerge from accounting numbers, thus increasing outside investors' activism, insiders tend more to resort to earnings aggressiveness, to disguise their misconduct [9]. There is also evidence that, in the presence of scant investor protection, opaque financial information, weak corporate governance and a high ownership concentration by families or the state, firms more involved in CSR practices want to demonstrate, tangibly, that they are acting in the interest of their stakeholders, and this attitude also reflects less earnings manipulation stimuli [17].

Very few studies have examined the relationship between earnings management and CSR disclosure. Some studies $[18,19]$ have analyzed whether CSR disclosure and EM are used in a substitutive or complementary relationship, as a response to political pressure; other authors have investigated the relationship between financial and CSR reporting quality [13]. Only the pioneering study of Sun et al. [20] has addressed the issue of a possible use of environmental information in order to disguise earnings manipulation. To the best of our knowledge, no research has taken into account the effect of the ultimate controlling owner nature on the relationship between EM and CSR disclosure. Prior studies have demonstrated that, relative to their non-family counterparts, family firms exhibit either different CSR disclosure practices [21,22] or attitudes towards earnings management [23,24]; therefore, it is of interest to examine the family effect on the relationship between EM and CSR disclosure, namely employing the latter to mask the former.

We addressed this issue by drawing on Institutional theory and Signaling theory, integrated with the socioemotional wealth (SEW) construct. We analyzed the extent of the CSR reporting of a sample of 226 Italian non-financial listed companies by computing a continuous disclosure index, for the period, 2006-2015. We took into account certain governance characteristics, accounting variables and the propensity to resort to accruals-based earnings management. The Italian setting is of particular interest for two main reasons. The first is that the institutional context may influence CSR disclosure usefulness [25-27] and also a firm's propensity to resort to earnings management practices [28]; empirical literature on the relation between earnings management and CSR disclosure has concentrated on Anglo-American contexts, while our study explores a new setting. The second is that family control is the prevalent form of ownership structure of both private and listed companies in Italy [29].

We found, for family firms, a significant positive relationship between negative discretionary accruals and the extent of CSR disclosure. We also found that this effect was enhanced by a firm's size and was moderated by the level of family ownership. This contributes to CSR disclosure/earnings management literature, focusing on the family-firm setting. We also add to family business studies by answering the call for empirical research grounded in the socioemotional wealth framework [30].

The remainder of the paper is organized as follows: Section 2 introduces the theoretical framework, the literary review and hypothesis development; Section 3 describes the data and methods; Section 4 provides the results and Section 5 discusses them; Section 6 concludes by pointing out limits and suggesting avenues for further research. 


\section{Theoretical Framework, Literature Review and Hypotheses Development}

\subsection{Theoretical Framework}

Most CSR disclosure literature relies on Institutional theory, which states that organizations behave in order to achieve external validation for their actions and legitimacy [4].

According to the legitimacy perspective, organizations try to demonstrate that their actions are consistent with the norms and values shared by society [31], because they are allowed to continue their operations by means of a social contract. When a company does not operate according to society's norms, a legitimacy gap emerges [2], putting the firm's very durability at risk [3,4]. "Legitimacy is a generalized perception or assumption that the actions of an entity are desirable, proper, or appropriate within some socially-constructed systems of norms, values, beliefs, and definitions" [5] (p. 574). It arises when community and relevant stakeholders endorse a firm's behavior as proper and useful [32]; therefore, organizations engage in informing their relevant public that they act consistently with the norms and limitations of society. A firm may also disclose its intended engagement in social issues, or divert attention from sensitive issues [6], as well as use communication to change the perception of its actions, or mask unethical behavior, or the low quality of its financial information, in order to protect or increase its legitimacy [7]. Through the lens of Institutional theory, CSR disclosure is viewed as one of the primary means that firms use to demonstrate that they behave consistently with the expectations of the community, or relevant stakeholders, or to affect stakeholders' perceptions of the firm with the ultimate aim of obtaining and maintaining their legitimacy to operate. A firm's organizational legitimacy is affected by its CSR reputation as well as by its financial reputation; CSR disclosure and financial reporting are mechanisms that shape the stakeholders' perceptions of these two reputational aspects. For this reason CSR reporting may be used as a tool for managing the reputational risk and avoid potential legitimacy gaps related to unethical practices [12].

Organizations engage in signaling their positive qualities [33] and therefore they behave consistently with ethic values. According to Signaling theory, an effective signal should be observable to the public and costly to imitate [34]. As a matter of fact, organizations may use a wide range of actions to communicate positive qualities, but not all actions are efficacious as signals. Observability is related to the receiver's ability to capture the signal; however, this characteristic, per se, is insufficient as, if a signal is imitable, the signaler will not be able to emerge from the crowd and communicate its particular qualities. Therefore, an effective signal should have a cost which cannot be absorbed by any signaler [35].

CSR disclosure is an observable signal of a firm's commitment to socially-responsible behavior. It is also a costly practice and its cost increases with the extension of the information provided.

The motivations underlying CSR disclosure [21] and unethical conduct, including earnings management $[23,24,36,37]$ in family firms, have been effectively addressed, based on the socioemotional wealth (SEW) approach. According to this relatively recent theoretical construct [38,39], family firms' behaviors are led, not only by financial objectives, but are strongly influenced by the desire to preserve the socioemotional wealth, described as "the non-financial aspects of the firm that meet the families' affective needs" [38], i.e., the affective endowment of the owning family in the firm [40]. Several dimensions characterize SEW [39] — the main dimension is related to the emotional value that the owning family experiences, by exerting its control and influence over the firm. Family members feel a strong sense of identification with the company that is seen as an extension of it, and through which, it also develops social ties with a wide range of stakeholders, such as employees, suppliers, customers, lenders and the community at large. The firm is the place where family members may satisfy their needs, in terms of belonging and affect [41]. The firm is also the means for perpetuating the family dynasty—by passing the business to future generations, family values and image survival [39]. 


\subsection{Literature Review and Hypotheses Development}

A few studies have addressed the relationship between earnings management and CSR disclosure. There is empirical evidence for the complementary use of these practices as a response to increased political pressure [18]. More generally, Yip et al. [19] suggest that the relationship between earnings management and CSR disclosure is context-specific. They argue that firms in industries with higher political costs show a positive relationship between CSR disclosure and earnings quality, whilst firms in industries with lower political costs employ CSR disclosure as a substitute for low-quality earnings. According to legitimacy arguments, firms involved in earnings management might be more prone to engaging in environmental disclosure, in order to generate the perception that their behavior is environmentally sensitive, and to divert attention from earnings manipulations. However, the literature has not found significant statistical evidence to support this motivation as a factor in explaining a firm's attitude towards environmental disclosure [20]. To the best of our knowledge, there are no studies addressing the relationship between earnings management and the extent of CSR disclosure in family firms, although extant literature suggests interesting differences between family and non-family firms, both for CSR disclosure behavior and for earnings management practices.

Over the past decades, the literature has widely engaged in the analysis of the determinants of CSR disclosure [1,31,42,43], but few studies have addressed this issue by focusing on family firms' behaviors. Campopiano and De Massis [21] analyzed the CSR disclosure behavior of 98 private and listed family and non-family firms, taking into account a wide range of communication types. Their sample focused on family-controlled companies, whose management is directly influenced by the presence of at least one family member. They found that family firms, relative to their non-family counterparts, are less compliant to Global Reporting Initiative (GRI) standards, but that they adopt a wider variety of CSR reports, as they want to increase actions which may benefit their reputation and improve the dialogue with their stakeholders. They also pointed out that family firms devote attention to different topics - in particular, they are more focused on those related to the environment and philanthropy, in order to protect their socioemotional wealth. Other studies have confirmed that family firms, in comparison with non-family companies, tend to put more emphasis on their involvement in philanthropic activities that give great visibility to the name of the family, promote its image and reinforce its reputation among the public and in the local community [44].

Research on sustainability reporting highlights heterogeneity in family business disclosure [22]. It points out that family control increases sustainability reporting when the family exerts a direct influence on the business, by appointing a family CEO, or by having the founder on the board; family ownership stake, per se, without family involvement on the board, negatively affects sustainability disclosure extent. Consistent with this, Cuadrado-Ballesteros et al. [45] found that a higher proportion of independent directors on the board lowered the transparency of CSR disclosure in family firms. There is also empirical evidence that social and environmental disclosure in family firms is more affected by media-exposure than in non-family businesses, as they are particularly concerned with the effect of visibility on reputation [22].

The above-mentioned motivations towards CSR disclosure behavior may also affect earnings management attitudes. Family firms are characterized by the owner family exerting more direct control over the board's activities, often by appointing family members as directors or having a family CEO, thereby reducing the incentive for managers to manipulate earnings for their own self-interest [46]. On the other hand, boards tend to be less independent and this fact undermines their monitoring of the controlling family, which may have more incentives for managing earnings, in order to expropriate minority shareholders [47-49], although a family firm's long-term perspective tends to moderate this behavior [50,51]. Regarding the effect of family ownership on earnings management, empirical findings are divergent. Wang [52] provides evidence of a negative association between founding family ownership and the level of abnormal accruals, even if the higher quality of earnings in family firms may be due either to the alignment between the interests of the founding family and those of other shareholders, or to the demand for higher-quality earnings from other shareholders, as compensation 
for weaker corporate governance mechanisms. Alternatively, Yang [53] highlights that the level of family ownership is negatively related to earnings quality, suggesting that the entrenchment of controlling families is detrimental to minority shareholders. Moreover, at a given level of family ownership, non-family CEOs have a higher propensity to engage in earnings management than family CEOs, since family firms rely more on earnings-based compensation plans to monitor and motivate these subjects than they do for family CEOs. Research has also examined the effect of certain corporate governance characteristics on earnings management, showing that board independence lowers earnings management. However, this effect is weaker in family than in non-family businesses, notably when the CEO is a family member. These findings suggest that, in family firms, even independent directors behave according to the owning family's will $[45,54,55]$. Consistent with these results, there is also evidence from the high-tech industry in Taiwan that board independence moderates a family business's propensity to resort to earnings management, but the effect is reversed in the presence of CEO duality [56]. Family and non-family firms show, instead, a similar attitude to using earnings management via R\&D cost capitalization, in order to avoid debt covenant violations, since family firms, to preserve the control of the owning family over the firm, distinctly prefer debt than equity capital and act to not harm the long-term relationships with lenders [28].

More recently, research has referred to the socioemotional wealth perspective, in order to study earnings management practices in family and non-family companies [24], providing evidence that the former are more prone to downward earnings management by means of higher negative discretionary accruals. Further, they tend to use real earnings management less than their non-family counterparts; an attitude that is accentuated when the founder serves as CEO. This behavior allows family firms to pay out lower dividends and turn resources into investments that increase a firm's future value, which is also protected from the detrimental effects that real earnings management generates in the long term. Other studies demonstrate that non-acquired family firms exhibit higher earnings quality than acquired family firms, because the former are inclined to avoid unethical practices, such as earnings management, due to closer identification of the family owners with the firm. This leads them to protect the firm's reputation and, thereby, the family's reputation, from the negative effects of earnings manipulation falling into the public domain [36]. Focusing on private family firms, Stokmans et al. [37] revealed that the need to preserve control over the firm, and subsequently, the SEW, is stronger in first-generation family firms and in founder-led family firms, compared with, respectively, subsequent-generation family firms and descendant-led family firms or externally-led family firms, notably when lenders want to protect their interests by placing covenants or appointing non-family members to the board. In such situations, the first type of family firm shows a greater propensity to use earnings management, in order to increase reported earnings when economic performance is negative or poorer than the prior year's performance. Martin et al. [23] found that family firms, compared with non-family firms, are less prone to engaging in earnings management practices, because they are more averse to the risk of earnings manipulations being detected. Such an event would harm the firm's image and cause a loss in SEW. Further, it would give rise to serious economic consequences, as the family's wealth is mainly concentrated in the firm. Unlike Stokmans et al. [37], Martin et al. [23] point out that the stronger intensity of SEW in founder-family firms, compared to subsequent-generation family firms, explains the lower degree of earnings management of the former. Founder owners are more committed to creating opportunities for the future growth of the firm and to building its reputation than are later generations, so they are mindful of putting their project at risk, which would be the case if questionable practices were revealed. In a similar way, for family owners of smaller firms, due to their closer involvement in the business-which reinforces the sense of identification with the firm - the protection of SEW leads to the avoidance of unethical behaviors, such as earnings management. Conversely, an increase in firm size often results in a loss of control that reduces the intensity of SEW and leaves room for such misconduct.

Extant literature highlights family firms' distinct reputational concerns [57], as they are aware that internal and external stakeholders perceive the company as an extension of the family [39]. 
Therefore, they are more committed to preventing damage to their constituents [58], they take more care of stakeholders' needs [59] and, for the same reason, they exhibit higher financial information transparency [23]. Nevertheless, a family firm may be motivated to manage reported earnings in order to preserve the owning family's financial and non-financial wealth. A family company may manage reported earnings downward, in order to reduce dividends and/or taxation, so as to preserve self-financing, and, therefore, family control [24], to the detriment of non-family shareholders and the state. On the other hand, a family firm may manage earnings upward, in order to prevent lenders interfering with board member appointments or covenant restrictions, or even to reduce the capability of raising debt financing, which might put family influence and control at risk [28,37]. A family business may also inflate reported earnings in order to increase a CEO's earnings-based compensation, particularly in the presence of a non-family CEO [53].

This unethical behavior, if detected, may seriously compromise a firm's image and the owning family's reputation-which are strictly linked [39]. A firm may try to divert attention from negative attributes, and/or conduct, which may generate damage. This is done by means of camouflage signals stating organizational legitimacy [60], such as CSR disclosure, as society positively values firms that engage in reporting their socially-responsible behaviors [61]. There is also evidence that family firms are particularly committed in stakeholders' proactive engagement [62] and that they benefit more significantly than their non-family counterparts from disclosing their involvement in CSR, in terms of market value, as their stakeholders perceive CSR disclosure as a positive signal of ethical commitment [25]. For the same reasons, family firms are less prone to engaging in unethical practices, such as earnings management, than non-family firms [23]. Given the owning families' concerns for reputation and image preservation [59], we expect that when family firms are involved in earnings management, they are more engaged in CSR disclosure than their non-family counterparts, as they are more motivated to highlight that their behavior complies with stakeholder expectations.

Hypothesis 1. In instances of earnings management practices, family firms are more prone than non-family businesses to resort to CSR disclosure.

Literature suggests that more visible firms, in terms of size or media exposure, attract attention from a broader community and that they react to visibility pressure through a greater commitment to social and environmental disclosure [43,63-67]. An increase in a firm's size also fosters the capability to absorb signal costs in terms of CSR disclosure extent. However, size may be a SEW moderator, as the management of larger firms implies the involvement of non-family members [30]. However, on the other hand, the potential reputational damage is higher for larger firms as they are more visible and more exposed to social scrutiny $[43,65]$. Family firms are particularly committed to avoiding the negative impacts of reputation loss [68] and the visibility of the family is positively associated with the family's concern for firm reputation [69]. We therefore expect that, in cases of earnings manipulation, the effect of a larger size on CSR disclosure, is stronger for family than for non-family firms.

Hypothesis 2. Size effect on the relationship between CSR disclosure and earnings management is higher for family than non-family firms.

\section{Data and Methodology}

The initial data sample of 289 firms comprised the entire population of non-financial firms listed on the Italian stock exchange in 2015, excluding insurance and financial firms, given their accounting and regulatory peculiarities. Then, we also removed state-controlled firms. We analyzed the period 2006-2015. As we needed at least two consecutive years of data to construct several explanatory variables, the final sample is represented by an unbalanced panel of 226 firms. The financial and accounting data were collected from the "Analisi Informatizzata Delle Aziende Italiane" (AIDA) database, using consolidated financial statements. Ownership data were reconstructed with a cross-check 
of the information available in the AIDA and Commissione Nazionale per le Società e la Borsa (CONSOB) databases.

The disclosure data was hand-collected from the stand-alone CSR reports available for each firm/year in the sample. We performed a content analysis, based on a list of 93 items, consistent with the Global Reporting Initiative (GRI) Sustainability Reporting Guidelines relevant topics and relative to stakeholder engagement, economic performance, environmental preservation, labor practices, human rights, society and product responsibility. As the literature suggests, GRI standards are a reference point for analyzing CSR [70]. We assigned a value of 1 if the item was disclosed and 0 otherwise. For each year, each firm had a Corporate Social Disclosure score $\left(\mathrm{CSD}_{\mathrm{i}, \mathrm{t}}\right)$ that ranged from 0 to 1 , calculated as $\operatorname{CSD}_{\mathrm{i}, \mathrm{t}}=\Sigma \mathrm{d}_{\mathrm{k}, \mathrm{i}, \mathrm{t}} / \mathrm{N}$, where $\mathrm{N}$ is the maximum number of items $\left(\mathrm{d}_{\mathrm{k}, \mathrm{i}, \mathrm{t}}\right)$ relevant for the firm $i$, thus excluding the items not relevant for each firm. In accordance with the methodology used by Haniffa and Cook [1] and Branco and Rodrigues [43], we assigned no penalty to items considered not relevant for a company's activity. This is the case with, for example, computer services and software industries regarding some of the environmental disclosure items, such as "total number and volume of significant spills", "biodiversity value of water bodies and related habitats significantly affected by discharges of water and runoff", etc. Following the methodology employed by Cook [71] and Haniffa and Cook [1], we read the entire report before making any decisions, so as to avoid bias in the judgment of relevance.

We defined a family firm as one where a family owns at least $20 \%$ of common shares [72]. To analyze the relationship between disclosure, earnings management and controlling shareholders, we took into account discretionary accruals and a number of control variables, which, according to many previous studies, may correlate with the extent of CSR disclosure: profitability, leverage, size, media exposure and presence of founder $[1,7,63,65]$. We measured profitability with the return to total assets ratio (Roa) [63]. Leverage was measured by the book value of the financial debt-to-equity ratio. We used two different measures of visibility: size [63,73]; and media exposure [63,74]. Size may be proxied by different measures that may lead to different results [75]. CSR disclosure literature has used the number of employees [76], market capitalization [65], and total assets [1,43,63,77-80], with consistent results. The literature has suggested the use of total assets as a proxy for a firm's visibility, in terms of environmental and social impact [78]; therefore, we chose to measure size by the $\log$ of total assets. Media exposure was taken as the number of articles containing the firm's name that appeared in the Italian financial newspaper "Il Sole 24 Ore" for each year of the sample period. This is the most popular and influential daily source of financial information in Italy, and its on-line database allowed us, using a firm's name as the keyword, to extract all articles on a sample company, without the risk of omissions. The founder was a dummy, taking into account the presence of the founder in the firm's management [38]. Controlling shareholders are likely to affect CSR disclosure. Family ownership in percentage (qFamily) is the weight of equity stakes held by family members [81]. Fboard is the weight (percent) of family members that sit on the board. These variables take into account the heterogeneity within family firms [82,83].

Accruals are the adjustments to delay or anticipate the recognition of cash flow in reported earnings. By exploiting the judgment inherent in some accounting choices, managers can anticipate or defer the recognition of revenues and expenses over time, in order to achieve specific earnings targets. We estimated discretionary accruals by drawing upon the modified Jones model [84] and using them to measure earnings management. We applied a cross-sectional analysis [85-87] and classified our sample firms, according to the Attività Economiche (ATECO) industry classification, retaining only the year-class with ten or more observations.

Total accruals (TA) were defined through the balance sheet approach $[23,85,88,89]$ as:

$$
\mathrm{TA}_{\mathrm{i}, \mathrm{t}}=\Delta \mathrm{CA}_{\mathrm{i}, \mathrm{t}}-\Delta \mathrm{CASH}_{\mathrm{i}, \mathrm{t}}-\Delta \mathrm{CL}_{\mathrm{i}, \mathrm{t}}+\Delta \mathrm{STD}_{\mathrm{i}, \mathrm{t}}-\mathrm{DEP}_{\mathrm{i}, \mathrm{t}}
$$

where: 
$\mathrm{TAi}_{\mathrm{i}, \mathrm{t}}=$ total accruals

$\Delta C A_{i, t}=$ change in current asset between period $t$ and $t-1$

$\Delta \mathrm{CASH}_{\mathrm{i}, \mathrm{t}}=$ change in cash and cash equivalents between period $\mathrm{t}$ and $\mathrm{t}-1$

$\Delta \mathrm{CL}_{\mathrm{i}, \mathrm{t}}=$ change in current liabilities between period $\mathrm{t}$ and $\mathrm{t}-1$

$\Delta \mathrm{STD}_{\mathrm{i}, \mathrm{t}}=$ change in short term debts included in current liabilities between period $\mathrm{t}$ and $\mathrm{t}-1$

$\mathrm{DEP}_{\mathrm{i}, \mathrm{t}}=$ depreciation and amortization expenses.

Non-discretionary accruals (NDA), namely the expected component of total accruals, arise from business activities and are sourced from change in revenue, which spills over into working capital variations and, in turn, causes an increase in the portion of earnings which has not yet produced cash flow. To reflect the idea that earnings are likely to be manipulated by means of sales on credit, rather than through cash sales, the change in accounts receivable was assumed to stem entirely from earnings management and the calculation of non-discretionary accruals and included only the change in cash sales $(\triangle \mathrm{REV}-\triangle \mathrm{REC})$. The estimation model also took into account the gross amount of property, plant and equipment (PPE), which influenced the level of depreciation expenses. Relying on these assumptions, the independent variables represented the drivers of non-discretionary accruals, while the accruals which are not explained by the model were qualified as discretionary accruals.

$$
\mathrm{TA}_{\mathrm{i}, \mathrm{t}} / \mathrm{A}_{\mathrm{i}, \mathrm{t}-1}=\alpha_{0}+\alpha_{1}\left(1 / \mathrm{A}_{\mathrm{i}, \mathrm{t}-1}\right)+\alpha_{2}\left[\left(\Delta \mathrm{REV}_{\mathrm{i}, \mathrm{t}}-\Delta \mathrm{REC}_{\mathrm{i}, \mathrm{t}}\right) / \mathrm{A}_{\mathrm{i}, \mathrm{t}-1}\right]+\alpha_{3}\left(\mathrm{PPE}_{\mathrm{i}, \mathrm{t}} / \mathrm{A}_{\mathrm{i}, \mathrm{t}-1}\right)+\varepsilon_{\mathrm{i}, \mathrm{t}}
$$

where:

$\mathrm{A}_{\mathrm{i}, \mathrm{t}-1}=$ lagged total assets

$\Delta R E V_{i, t}=$ change in revenues between period $t$ and $t-1$

$\triangle \mathrm{REC}_{\mathrm{i}, \mathrm{t}}=$ change in trade receivables between period $\mathrm{t}$ and $\mathrm{t}-1$

$\mathrm{PPE}_{\mathrm{i}, \mathrm{t}}=$ gross property, plant and equipment.

The coefficients in Equation (2) were estimated cross-sectionally by regressing financial statement values for each firm in the same industry. These coefficients were then applied, to estimate the non-discretionary accruals for firm $\mathrm{i}$ in period $\mathrm{t}$ :

$$
\mathrm{NDA}_{i, t} / \mathrm{A}_{\mathrm{i}, \mathrm{t}-1}=\mathrm{a}_{0}+\mathrm{a}_{1}\left(1 / \mathrm{A}_{\mathrm{i}, \mathrm{t}-1}\right)+\mathrm{a}_{2}\left[\left(\mathrm{REV}_{\mathrm{i}, \mathrm{t}}-\Delta \mathrm{REC}_{\mathrm{i}, \mathrm{t}}\right) / \mathrm{A}_{\mathrm{i}, \mathrm{t}-1}\right]+\mathrm{a}_{3}\left(\mathrm{PPE}_{\mathrm{i}, \mathrm{t}} / \mathrm{A}_{\mathrm{i}, \mathrm{t}-1}\right)
$$

Finally, discretionary accruals (DA) for firm i in period $t$ were calculated as the difference between total accruals and non-discretionary accruals (all variables were scaled by lagged total assets):

$$
\mathrm{DA}_{\mathrm{i}, \mathrm{t}}=\mathrm{TA}_{\mathrm{i}, \mathrm{t}}-\mathrm{NDA}_{\mathrm{i}, \mathrm{t}}
$$

To verify the hypotheses from the previous section, we used panel regressions, with coefficients estimated using generalized least squares; using the longitudinal data set, we also standardized all non-binary variables reducing the likelihood of multicollinearity problems. The reported standard errors were robust for the presence of correlations across firms, time and industry, using clustering at the firm level and introducing year dummies and industry sector dummies. We implemented an explanatory model, as follows:

$$
\mathrm{CSD}_{\mathrm{i}, \mathrm{t}}=\beta_{0}+\beta_{1} \mathrm{DA}_{\mathrm{i}, \mathrm{t},+(-)}+\sum \beta_{\mathrm{j}} \mathrm{X}_{\mathrm{j}, \mathrm{i}, \mathrm{t}}+\sum \beta_{\mathrm{k}} \mathrm{X}_{\mathrm{k}, \mathrm{i}, \mathrm{t}}+\varepsilon_{\mathrm{i}, \mathrm{t}}
$$

where:

$\mathrm{DA}_{\mathrm{i}, \mathrm{t},+(-)}=$ positive (negative) discretionary accruals for firm $\mathrm{i}$ in period $\mathrm{t}$

$\mathrm{X}_{\mathrm{i}, \mathrm{i}, \mathrm{t}}=$ controlling shareholders variables

$\mathrm{X}_{\mathrm{k}, \mathrm{i}, \mathrm{t}}=$ control variables. 
To incorporate the possible interaction effects between discretionary accruals and other variables, such as size, founder, family on the board and family ownership, we implemented the augmented model:

$$
\mathrm{CSD}_{\mathrm{i}, \mathrm{t}}=\beta_{0}+\beta_{1} \mathrm{DA}_{\mathrm{i}, \mathrm{t},+(-)}+\sum \beta_{\mathrm{j}} \mathrm{X}_{\mathrm{j}, \mathrm{i}, \mathrm{t}}+\sum \beta_{\mathrm{k}} \mathrm{X}_{\mathrm{k}, \mathrm{i}, \mathrm{t}}+\sum \beta_{\mathrm{w}} \text { Interaction variables }+\varepsilon_{\mathrm{i}, \mathrm{t}}
$$

As the causal relation between earnings management and CSR actions could be simultaneous or reversed, CSR disclosure and earnings management could be endogenously determined, and this could have resulted in simultaneity, reversed causality or other endogeneity problems in model estimation. To address these concerns, empirical corporate finance literature uses a variety of methods: fixed effects, control variables, lagged variables, generalized method of moments (GMM) [90-100]. Following $\mathrm{Li}$ [90], we verified the robustness of our results using two of the above techniques to mitigate the endogeneity concerns, using lagged independent variables and fixed effects for year and industry.

\section{Results}

In Table 1, we present descriptive statistics for family and non-family firms. Family firms engaged more frequently in CSR disclosure than non-family firms. The result of the $t$-test on the mean disclosure scores was highly significant.

The mean values of total accruals were similar for family and non-family firms, while the mean value of discretionary accruals, either in absolute terms or distinguishing negative (DAM) and positive (DAP) disposals, was significantly higher for non-family firms than for family businesses. Family firms were also more visible, more levered and more profitable than non-family firms.

The data indicate that the founder is more likely to be on the board of a family firm, that the average family equity stake is around 60 per cent and that more than a quarter of board members in family firms are family members.

Table 1. Descriptive statistics.

\begin{tabular}{|c|c|c|c|c|c|}
\hline \multirow{2}{*}{ Panel A } & \multicolumn{2}{|c|}{ Family Firms } & \multicolumn{2}{|c|}{ Non-Family Firms } & \multirow{2}{*}{$\mathrm{t}$} \\
\hline & Mean & SD & Mean & SD & \\
\hline TA & -0.049 & 0.133 & -0.055 & 0.181 & -0.82 \\
\hline DAM & -0.077 & 0.075 & -0.095 & 0.114 & $-2.98 * * *$ \\
\hline DAP & 0.073 & 0.071 & 0.094 & 0.109 & $3.28 * * *$ \\
\hline Abs (DA) & 0.075 & 0.073 & 0.095 & 0.111 & $4.48^{* * * *}$ \\
\hline Size & 12.710 & 1.769 & 12.002 & 1.938 & $-8.41^{* * *}$ \\
\hline Leverage & 1.480 & 9.799 & 1.218 & 15.647 & -1.09 \\
\hline Roa & 0.020 & 0.084 & -0.017 & 0.129 & $-6.95 * * *$ \\
\hline CSD & 0.076 & 0.218 & 0.046 & 0.169 & $-3.45^{* * *}$ \\
\hline Media Exposure & 11.319 & 28.156 & 8.665 & 21.793 & $2.39 * *$ \\
\hline Founder & 0.530 & - & 0.360 & - & \\
\hline qFamily & 0.596 & 0.151 & - & - & \\
\hline Fboard & 0.270 & 0.197 & - & - & \\
\hline Obs & 972 & & 877 & & \\
\hline \multicolumn{2}{|l|}{ Panel B } & & & $\begin{array}{c}\text { Family } \\
\text { Firms }\end{array}$ & Non-Family Firms \\
\hline \multicolumn{4}{|c|}{ Apparel \& Textile } & 15 & 4 \\
\hline \multicolumn{4}{|c|}{ Chemical \& Farmaceutical } & 18 & 6 \\
\hline \multicolumn{4}{|c|}{ Computer \& Household } & 10 & 5 \\
\hline \multicolumn{4}{|c|}{ Industrial, Commercial and Transportation Equipment } & 16 & 7 \\
\hline \multicolumn{4}{|c|}{ Utilities \& Related Services } & 10 & 22 \\
\hline \multicolumn{4}{|c|}{ Construction \& Building Materials } & 12 & 11 \\
\hline \multicolumn{4}{|c|}{ Wholesale \& Retail Trade } & 10 & 10 \\
\hline \multirow{2}{*}{\multicolumn{4}{|c|}{$\begin{array}{l}\text { Publishing, Motion \& Enterteinment } \\
\text { Digital Solutions, Software and Consulting }\end{array}$}} & 12 & 11 \\
\hline & & \multicolumn{2}{|c|}{ Digital Solutions, Software and Consulting } & 8 & 21 \\
\hline \multicolumn{4}{|c|}{ Real Estate } & 7 & 11 \\
\hline \multicolumn{4}{|c|}{ TOTAL } & 118 & 108 \\
\hline
\end{tabular}

TA is total accruals, DAM (DAP) is negative (positive) discretionary accruals, Abs (DA) is the absolute value of discretionary accruals. Size is measured by the log of assets, Leverage is the book value of financial debt-to-equity ratio, Roa is the return to total assets ratio, CSD is the corporate social disclosure score. Media exposure is the yearly number of articles related to a firm appeared on the "Il Sole 24 Ore" newspaper, founder is a dummy taking into account the presence of the founder in the firm's management, qFamily is the weight of equity stakes held by family members, Fboard is the weight of family members that sit on the board. ${ }^{* * *}$ Indicate significance at the $1 \%$ level; *** Indicate significance at the $5 \%$ level. 
In Table 2 we report the correlation coefficiens for the dependent and explanatory variables.

Table 2. Correlations Matrix.

\begin{tabular}{cccccccccc}
\hline & CSD & $\begin{array}{c}\text { Media } \\
\text { Exposure }\end{array}$ & DAM & DAP & ROA & Lev & Size & Founder & qFam \\
\hline Media Exposure & $0.313^{* * *}$ & & & & & & & & \\
DAM & $0.051^{* *}$ & 0.021 & & & & & & & \\
DAP & 0.028 & -0.003 & $0.296^{* * *}$ & & & & & & \\
ROA & $0.041^{*}$ & $0.077^{* * *}$ & $0.202^{* * *}$ & 0.018 & & & & & \\
Leverage & -0.020 & -0.021 & -0.008 & -0.009 & -0.026 & & & & \\
Size & $-0.328^{* * *}$ & $0.418^{* * *}$ & $0.103^{* * *}$ & -0.015 & $0.124^{* * *}$ & -0.022 & & & \\
Founder & $-0.074^{* * *}$ & $-0.199^{* * *}$ & 0.020 & -0.009 & $0.081^{* * *}$ & 0.008 & $-0.239^{* * *}$ & & \\
qFamily & $-0.045^{*}$ & 0.018 & $0.094^{* * *}$ & -0.011 & $0.183^{* * *}$ & 0.024 & $0.165^{* * *}$ & $0.151^{* * *}$ & \\
Fboard & $-0.045^{*}$ & $-0.063^{* * *}$ & $0.065^{* * *}$ & $-0.039^{*}$ & $0.135^{* * *}$ & 0.001 & -0.006 & $0.173^{* * *}$ & $0.657^{* * *}$ \\
\hline
\end{tabular}

${ }^{* * *}$ Indicate significance at the $1 \%$ level; ${ }^{* *}$ Indicate significance at the $5 \%$ level; ${ }^{*}$ Indicate significance at the $10 \%$ level.

Table 4 presents the generalized least squares (GLS) panel model results, based on the models in Equations (4) and (5). The findings in the base model indicate that negative discretionary accruals have a positive effect on CSR disclosure in family firms, but they do not affect the propensity to disclose of non-family firms. Looking at positive discretionary accruals, we did not find any relationship between these disposals and the degree of disclosure. Consistent with previous studies, we found that our measures of visibility, namely media exposure and size, had a high positive effect on family firms' disclosure, while the results for non-family firms were mixed, and media exposure did not seem to be significant for explaining levels of disclosure [43,63-66]. The founder presence on the board and leverage did not seem to affect CSR practices. The introduction of family specific variables and interaction terms confirmed these results and showed that, for the family firms subsample, the variability in family equity stakes, or in the weight of family members on the board, increase marginally the explanatory power of our model. The interaction terms of negative discretionary accruals with size and family equity stake showed a significant effect on disclosure.

Table 3. Panel GLS Regressions with firm clustered standard errors.

\begin{tabular}{|c|c|c|c|c|c|c|}
\hline Panel A & Family & Non-Family & Family & VIF & Non-Family & VIF \\
\hline Intercept & $0.055(0.18)^{* * *}$ & $0.058(0.019)^{* * *}$ & $0.055(0.18)^{* * *}$ & 1.30 & $0.057(0.019)^{* * *}$ & 1.27 \\
\hline Media Exposure & $0.054(0.023)^{* *}$ & $0.023(0.028)$ & $0.054(0.022) * *$ & 2.12 & $0.024(0.028)$ & 1.77 \\
\hline DAM & $0.010(0.006)^{*}$ & $0.000(0.005)$ & $0.010(0.006) *$ & 1.09 & $-0.000(0.007)$ & 1.14 \\
\hline $\mathrm{ROA}$ & $-0.020(0.009)^{* *}$ & $0.013(0.010)$ & $-0.020(0.009)^{* *}$ & 1.02 & $0.013(0.010)$ & 1.00 \\
\hline Leverage & $-0.005(0.003) *$ & $-0.001(0.001)$ & $-0.005(0.003)$ & 1.32 & $-0.001(0.001)$ & 1.46 \\
\hline Size & $0.067(0.022)^{* * *}$ & $0.035(0.017)^{* *}$ & $0.065(0.021)^{* * *}$ & 1.10 & $0.033(0.016)^{* *}$ & 1.14 \\
\hline Founder & $0.035(0.032)$ & $-0.027(0.022)$ & $0.038(0.032)$ & 1.05 & $-0.029(0.021)$ & \\
\hline qFamily & & & $-0.008(0.011)$ & 1.10 & & \\
\hline Fboard & & & $-0.017(0.011)$ & 1.16 & & 10.25 \\
\hline $\mathrm{DAM}^{*}$ Size & & & $0.026(0.009)^{* * *}$ & 2.38 & $0.022(0.013)$ * & 10.95 \\
\hline DAM*Founder & & & $0.005(0.014)$ & 1.20 & $0.007(0.006)$ & 10.27 \\
\hline DAM*qFamily & & & $-0.013(0.007) *$ & 1.31 & & \\
\hline DAM*Fboard & & & $-0.005(0.005)$ & 1.30 & & \\
\hline $\mathrm{R}^{2}$ & 0.20 & 0.09 & 0.23 & & 0.10 & \\
\hline Obs & 958 & 713 & 915 & & 713 & \\
\hline Panel B & Family & Non-Family & Family & VIF & Non-Family & VIF \\
\hline Interc. & $0.058(0.019)^{* * *}$ & $0.061(0.019)^{* * *}$ & $0.059(0.019)^{* * *}$ & 1.27 & $0.059(0.019)^{* * *}$ & 1.25 \\
\hline Media Exposure & $0.054(0.024)^{* *}$ & $0.025(0.027)$ & $0.052(0.024) * *$ & 2.05 & $0.023(0.026)$ & 1.68 \\
\hline DAP & $0.002(0.006)$ & $0.014(0.014)$ & $0.008(0.009)$ & 1.05 & $0.019(0.017)$ & 1.03 \\
\hline ROA & $-0.017(0.008)^{* *}$ & $0.014(0.008)$ * & $-0.017(0.009)^{* *}$ & 1.03 & $0.012(0.008)$ & 1.00 \\
\hline Leverage & $-0.005(0.003) *$ & $-0.000(0.001)$ & $-0.005(0.003) *$ & 1.31 & $-0.000(0.001)$ & 1.47 \\
\hline Size & $0.063(0.021)^{* * *}$ & $0.028(0.013)^{* *}$ & $0.062(0.021)^{* * *}$ & 1.09 & $0.032(0.013) * *$ & 1.19 \\
\hline Founder & $0.035(0.031)$ & $-0.028(0.013)^{* *}$ & $0.041(0.033)$ & 1.05 & $-0.026(0.020)$ & \\
\hline qFamily & & & $-0.005(0.011)$ & 1.15 & & \\
\hline
\end{tabular}


Table 3. Cont.

\begin{tabular}{|c|c|c|c|c|c|c|}
\hline Panel B & Family & Non-Family & Family & VIF & Non-Family & VIF \\
\hline Fboard & & & $-0.015(0.011)$ & 1.19 & & 1.32 \\
\hline DAP*Size & & & $0.020(0.010) *$ & 1.82 & $0.018(0.010) *$ & 1.95 \\
\hline DAP*Founder & & & $-0.009(0.014)$ & 1.12 & $-0.013(0.016)$ & 1.25 \\
\hline DAP* qFamily & & & $0.006(0.006)$ & 1.39 & & \\
\hline DAP*Fboard & & & $0.002(0.006)$ & 1.27 & & \\
\hline $\mathrm{R}^{2}$ & 0.19 & 0.10 & 0.021 & & 0.11 & \\
\hline Obs & 972 & 766 & 929 & & 766 & \\
\hline
\end{tabular}

DAM(DAP)*Size, DAM(DAP)*Founder, DAM(DAP)* $q$ Family, DAM(DAP)*Fboard measure interaction effects between discretionary accruals and size, founder, qFamily and Fboard. VIF is the Variance Inflation Factor. *** Indicate significance at the $1 \%$ level; ${ }^{* *}$ Indicate significance at the $5 \%$ level; ${ }^{*}$ Indicate significance at the $10 \%$ level.

As we have a panel longitudinal dataset, we estimated Equations (4) and (5), by calculating clustered standard errors, to account for the firm fixed effects. This procedure gives unbiased standard errors as long as the time effects, or other fixed effects (e.g., industrial sectors) are negligible.

The simultaneity of CSR disclosure and discretionary accruals and the omission of relevant variables may also result in endogeneity problems. The direction of causality between CSR disclosure and discretionary accruals can be reverse, or run both ways. We addressed these problems using two methods. The first approach was to cluster for the firm dimension and parametrically account for the time and industry fixed effects, including year and industrial sector dummies. This technique tries to control for some of the unobservable determinants of CSR disclosure, to reduce the omitted variables bias. The second approach investigated the relationship between discretionary accruals and the other explanatory variables on subsequent CSR disclosure. The panel GLS regressed CSR disclosure in year $(t+1)$ on discretionary accruals and the other variables in year $t$. To control for bias due to omitted variables, we also added to the model, the fixed effects for year and industrial sector and cluster for the firm dimension.

We present in Table 4, the estimates using the first approach, to account jointly for the contextual presence of the fixed effects.

Table 4. Panel GLS Regressions with firm-level clustering, time and industry fixed effects.

\begin{tabular}{|c|c|c|c|c|c|c|}
\hline Panel A & Family & Non-Family & Family & \multirow{2}{*}{ VIF } & Non-Family & \multirow{2}{*}{ VIF } \\
\hline Interc. & N/A & N/A & N/A & & N/A & \\
\hline Media Exposure & $0.055(0.023)$ ** & $0.030(0.025)$ & $0.056(0.022) * *$ & 1.34 & $0.030(0.025)$ & 1.34 \\
\hline DAM & $0.009(0.005) *$ & $-0.000(0.005)$ & $0.008(0.005) *$ & 2.16 & $-0.003(0.006)$ & 1.82 \\
\hline ROA & $-0.014(0.009)$ & $0.013(0.009)$ & $-0.013(0.009)$ & 1.20 & $0.013(0.009)$ & 1.27 \\
\hline Leverage & $-0.006(0.004)$ & $-0.002(0.003)$ & $-0.006(0.004)$ & 1.04 & $-0.002(0.003)$ & 1.03 \\
\hline Size & $0.064(0.021)^{* * *}$ & $0.044(0.017)^{* * *}$ & $0.063(0.020)^{* * *}$ & 1.50 & $0.042(0.016)^{* * *}$ & 1.65 \\
\hline Founder & $0.039(0.029)$ & $-0.029(0.021)$ & $0.045(0.030)$ & 2.29 & $-0.030(0.021)$ & 1.79 \\
\hline Year fixed effect & Yes & Yes & Yes & 1.09 & Yes & \\
\hline $\begin{array}{c}\text { Industry fixed } \\
\text { effect }\end{array}$ & Yes & Yes & Yes & 1.23 & Yes & \\
\hline qFamily & & & $-0.004(0.011)$ & 1.20 & & 1.29 \\
\hline Fboard & & & $-0.021(0.013)$ * & 2.42 & & 2.00 \\
\hline DAM $^{*}$ Size & & & $0.028(0.008)^{* * *}$ & 1.23 & $0.015(0.010)$ & 1.34 \\
\hline DAM*Founder & & & $0.009(0.012)$ & 1.33 & $0.010(0.009)$ & 1.82 \\
\hline DAM*qFamily & & & $-0.008(0.007)$ & 1.34 & & \\
\hline DAM*Fboard & & & $-0.006(0.005)$ & 2.16 & & \\
\hline$R^{2}$ & 0.33 & 0.26 & 0.36 & & 0.27 & \\
\hline Obs & 958 & 713 & 915 & & 713 & \\
\hline Panel B & Family & Non-Family & Family & VIF & Non-Family & VIF \\
\hline Interc. & $\mathrm{N} / \mathrm{A}$ & $\mathrm{N} / \mathrm{A}$ & $\mathrm{N} / \mathrm{A}$ & & $\mathrm{N} / \mathrm{A}$ & \\
\hline Media Exposure & $0.055(0.023) * *$ & $0.032(0.025)$ & $0.054(0.023)^{* *}$ & 1.31 & $0.030(0.023)$ & 1.33 \\
\hline DAP & $0.003(0.006)$ & $0.015(0.012)$ & $0.008(0.008)$ & 2.12 & $0.016(0.014)$ & 1.70 \\
\hline $\mathrm{ROA}$ & $-0.010(0.009)$ & $0.015(0.009)^{*}$ & $-0.010(0.010)$ & 1.16 & $0.013(0.008)$ & 1.14 \\
\hline Leverage & $-0.006(0.004)$ & $-0.001(0.002)$ & $-0.006(0.004)$ & 1.05 & $-0.002(0.002)$ & 1.02 \\
\hline Size & $0.059(0.020)^{* * *}$ & $0.032(0.013)^{* *}$ & $0.058(0.020)^{* * *}$ & 1.46 & $0.037(0.013) * * *$ & 1.60 \\
\hline
\end{tabular}


Table 4. Cont.

\begin{tabular}{|c|c|c|c|c|c|c|}
\hline Panel B & Family & Non-Family & Family & VIF & Non-Family & VIF \\
\hline Founder & $0.038(0.029)$ & $-0.032(0.021)$ & $0.046(0.031)$ & 2.24 & $-0.029(0.020)$ & 1.98 \\
\hline Year fixed eff. & Yes & Yes & Yes & 1.10 & Yes & \\
\hline Industry fixed eff. & Yes & Yes & Yes & 1.28 & Yes & \\
\hline qFamily & & & $-0.001(0.011)$ & 1.21 & & 1.35 \\
\hline Fboard & & & $-0.019(0.013)$ & 1.85 & & 1.98 \\
\hline DAP*Size & & & $0.019(0.010)^{*}$ & 1.14 & $0.025(0.010) * *$ & 1.33 \\
\hline DAP*Founder & & & $-0.007(0.014)$ & 1.43 & $-0.025(0.016)$ & 1.70 \\
\hline DAP* ${ }^{*}$ Family & & & $0.003(0.005)$ & 1.31 & & \\
\hline DAP*Fboard & & & $0.002(0.005)$ & 2.12 & & \\
\hline$R^{2}$ & 0.32 & 0.26 & 0.34 & & 0.27 & \\
\hline Obs & 972 & 766 & 929 & & 766 & \\
\hline
\end{tabular}

*** Indicate significance at the $1 \%$ level; ${ }^{* *}$ Indicate significance at the $5 \%$ level; ${ }^{*}$ Indicate significance at the $10 \%$ level.

Overall, the explanatory variables maintained their sign and significance, and the explicative power of our models ranged from 0.32 to 0.36 for the family firms, and from 0.26 to 0.27 for the non-family firms.

Table 5 presents the results using the second approach, lagging the independent variables and controlling for the year and industrial sector fixed effects.

With lagged variables the explicative power of our models ranged from 0.35 to 0.38 for the family firms, and from 0.28 to 0.29 for the non-family firms. Tables 4 and 5 indicate a moderate increase in the standard errors, due to the time and industry fixed effects. However, this did not have a sizable impact on the results reported in Table 4 for family firms.

Table 5. Panel GLS Regressions with firm-level clustering, time and industry fixed effects with lagged independent variables.

\begin{tabular}{|c|c|c|c|c|c|c|}
\hline Panel A & Family & Non-Family & Family & \multirow[t]{2}{*}{ VIF } & Non-Family & \multirow{2}{*}{ VIF } \\
\hline Interc. & N/A & N/A & N/A & & N/A & \\
\hline Media Exposure & $0.102(0.048)^{* *}$ & $0.032(0.029)$ & $0.105(0.042)^{* *}$ & 1.52 & $0.033(0.029)$ & 1.39 \\
\hline DAM & $0.012(0.006)^{* *}$ & $-0.003(0.005)$ & $0.019(0.009)^{* * *}$ & 2.29 & $-0.008(0.007)$ & 1.94 \\
\hline ROA & $-0.010(0.009)$ & $0.021(0.012) *$ & $-0.016(0.011)$ & 1.22 & $0.022(0.012) *$ & 1.38 \\
\hline Leverage & $-0.007(0.004)$ & $-0.001(0.003)$ & $-0.007(0.004)$ & 1.05 & $-0.002(0.003)$ & 1.03 \\
\hline Size & $0.060(0.023)^{* * *}$ & $0.048(0.020)^{* *}$ & $0.058(0.022)^{* * * *}$ & 1.63 & $0.045(0.020)^{* *}$ & 1.62 \\
\hline Founder & $0.040(0.032)$ & $-0.033(0.025)$ & $0.049(0.034)$ & 2.46 & $-0.034(0.025)$ & 1.80 \\
\hline Year fixed eff. & Yes & Yes & Yes & & Yes & \\
\hline Industry fixed eff. & Yes & Yes & Yes & & Yes & \\
\hline qFamily & & & $-0.003(0.012)$ & 1.08 & & \\
\hline Fboard & & & $-0.023(0.013)$ * & 1.24 & & \\
\hline $\mathrm{DAM}^{*}$ Size & & & $0.027(0.012)^{* *}$ & 1.14 & $0.021(0.011) *$ & 1.30 \\
\hline $\mathrm{DAM}^{*}$ Founder & & & $-0.007(0.015)$ & 2.44 & $0.017(0.010)$ * & 2.02 \\
\hline DAM*gFamily & & & $-0.014(0.008)$ * & $\begin{array}{l}2.44 \\
1.20\end{array}$ & & \\
\hline DAM*Fboard & & & $-0.006(0.005)$ & 1.33 & & \\
\hline$R^{2}$ & 0.35 & 0.28 & 0.38 & & 0.29 & \\
\hline Obs & 840 & 611 & 802 & & 611 & \\
\hline Panel B & Family & Non-Family & Family & VIF & Non-Family & VIF \\
\hline Interc. & $\mathrm{N} / \mathrm{A}$ & $\mathrm{N} / \mathrm{A}$ & $\mathrm{N} / \mathrm{A}$ & & $\mathrm{N} / \mathrm{A}$ & \\
\hline Media Exposure & $0.102(0.048)^{* *}$ & $0.034(0.028)$ & $0.100(0.047)^{* *}$ & 1.46 & $0.032(0.026)$ & 1.36 \\
\hline DAP & $0.001(0.006)$ & $0.026(0.013)$ * & $0.004(0.009)$ & 2.05 & $0.029(0.016)$ * & 2.06 \\
\hline ROA & $-0.006(0.009)$ & $0.021(0.010)$ * & $-0.007(0.010)$ & 1.18 & $0.019(0.010)$ * & 1.16 \\
\hline Leverage & $-0.007(0.004)$ & $-0.001(0.003)$ & $-0.007(0.004)$ & 1.06 & $-0.001(0.003)$ & 1.02 \\
\hline Size & $0.055(0.021)^{* *}$ & $0.034(0.015)^{* *}$ & $0.054(0.021)^{* *}$ & 1.58 & $0.039(0.015)^{* *}$ & 1.61 \\
\hline Founder & $0.039(0.032)$ & $-0.036(0.024)$ & $0.048(0.034)$ & 2.41 & $-0.033(0.024)$ & 2.05 \\
\hline Year fixed effects & Yes & Yes & Yes & & Yes & \\
\hline $\begin{array}{l}\text { Industry fixed } \\
\text { effects }\end{array}$ & Yes & Yes & Yes & & Yes & \\
\hline qFamily & & & $0.000(0.010)$ & 1.10 & & \\
\hline Fboard & & & $-0.019(0.013)$ & 1.30 & & \\
\hline DAP*Size & & & $0.021(0.010)^{* * *}$ & 1.20 & $0.023(0.010)^{* * *}$ & 1.60 \\
\hline DAP*Founder & & & $-0.005(0.015)$ & 1.84 & $-0.013(0.018)$ & 2.41 \\
\hline DAP* ${ }^{*}$ Family & & & $-0.006(0.008)$ & $\begin{array}{l}1.07 \\
1.19\end{array}$ & & \\
\hline DAP*Fboard & & & $0.004(0.007)$ & 1.48 & & \\
\hline$R^{2}$ & 0.35 & 0.28 & 0.36 & & 0.29 & \\
\hline Obs & 854 & 660 & 816 & & 660 & \\
\hline
\end{tabular}

\footnotetext{
*** Indicate significance at the $1 \%$ level; ${ }^{* *}$ Indicate significance at the $5 \%$ level; ${ }^{*}$ Indicate significance at the $10 \%$ level.
} 
Another source of concern with the above results could be related to the family firm definition used. Although the threshold of 20 percent ownership, in analyzing listed firms, is consistent with those used in literature [72,101], there is no consensus on the definition of a family business. Instead, various definitions have been proposed, based on several ownership thresholds, and ownership and governance involvement of the owning family. To make sure that our conclusions are not driven from this definition, we show, in Table 6, the augmented model using two alternative definitions of family firm. Using the first one, family firms are only those where a family owns 50 percent or more of the shares; the firms that do not meet this target are considered non-family businesses. With the second definition, to be considered a family enterprise, the family must own 50 percent or more of the firm and also be actively involved in the governance, with at least one family member sitting on the board.

The explicative power of the model remains the same for the non-family firms and we have a little improvement in the case of family firms using more narrow family firm definitions. The results are robust for alternative family firm definitions, but we cannot rule out the possibility that the characteristics of the Italian listed family and non-family firms may influence the results.

Table 6. Panel GLS Regressions with firm-level clustering, time and industry fixed effects with lagged independent variables (alternative family firm definitions).

\begin{tabular}{|c|c|c|c|c|}
\hline \multirow[b]{3}{*}{ Panel A } & \multicolumn{4}{|c|}{ Alternative Family Firms Definitions } \\
\hline & \multicolumn{2}{|c|}{ qFamily $\geq \mathbf{5 0} \%$} & \multicolumn{2}{|c|}{ qFamily $\geq \mathbf{5 0} \%$ + Family in Governance } \\
\hline & Family & Non-Family & Family & Non-Family \\
\hline Interc. & $\mathrm{N} / \mathrm{A}$ & $\mathrm{N} / \mathrm{A}$ & $\mathrm{N} / \mathrm{A}$ & $\mathrm{N} / \mathrm{A}$ \\
\hline Media Exposure & $0.104(0.042) * *$ & $0.032(0.030)$ & $0.114(0.042) * *$ & $0.028(0.029)$ \\
\hline DAM & $0.019(0.009)^{* *}$ & $-0.008(0.007)$ & $0.023(0.011) * *$ & $-0.006(0.007)$ \\
\hline ROA & $-0.015(0.011)$ & $0.020(0.012)^{*}$ & $-0.020(0.012)$ & $0.020(0.011)^{*}$ \\
\hline Leverage & $-0.007(0.004)$ & $-0.003(0.003)$ & $-0.007(0.009)$ & $-0.004(0.003)$ \\
\hline Size & $0.058(0.022)^{* * *}$ & $0.029(0.019)^{* *}$ & $0.043(0.022) * * *$ & $0.062(0.023) * *$ \\
\hline Founder & $0.049(0.034)$ & $-0.037(0.025)$ & $0.041(0.034)$ & $-0.012(0.023)$ \\
\hline Year fixed effects & Yes & Yes & Yes & Yes \\
\hline Industry fixed effects & Yes & Yes & Yes & Yes \\
\hline qFamily & $-0.008(0.015)$ & & $-0.017(0.015)$ & \\
\hline Fboard & $-0.021(0.014)$ & & $-0.018(0.016)$ & \\
\hline DAM*Size & $0.027(0.012) * *$ & $0.021(0.011) *$ & $0.025(0.012)^{* *}$ & $0.025(0.010) *$ \\
\hline DAM*Founder & $-0.006(0.015)$ & $0.016(0.010)$ & $-0.010(0.016)$ & $0.017(0.010)$ \\
\hline DAM*qFamily $^{*}$ & $-0.016(0.009)^{*}$ & & $-0.019(0.010)^{*}$ & \\
\hline DAM*Fboard & $-0.005(0.005)$ & & $-0.005(0.005)$ & \\
\hline $\mathrm{R}^{2}$ & 0.38 & 0.28 & 0.40 & 0.28 \\
\hline Obs & 794 & 616 & 723 & 728 \\
\hline Panel B & Family & Non-Family & Family & Non-Family \\
\hline Interc. & $\mathrm{N} / \mathrm{A}$ & $\mathrm{N} / \mathrm{A}$ & $\mathrm{N} / \mathrm{A}$ & $\mathrm{N} / \mathrm{A}$ \\
\hline Media Exposure & $0.098(0.047)^{* *}$ & $0.031(0.027)$ & $0.108(0.048)^{* *}$ & $0.027(0.026)$ \\
\hline DAP & $-0.004(0.009)$ & $0.031(0.016) *$ & $0.010(0.010)$ & $0.020(0.015) *$ \\
\hline ROA & $-0.006(0.010)$ & $0.017(0.010) *$ & $-0.011(0.012)$ & $0.018(0.009) *$ \\
\hline Leverage & $-0.007(0.004)$ & $-0.002(0.003)$ & $-0.008(0.009)$ & $-0.003(0.003)$ \\
\hline Size & $0.054(0.021)^{* *}$ & $0.038(0.015)^{* *}$ & $0.040(0.020)^{*}$ & $0.055(0.020)^{* * *}$ \\
\hline Founder & $0.048(0.034)$ & $-0.035(0.023)$ & $0.042(0.035)$ & $-0.010(0.028)$ \\
\hline Year fixed effects & Yes & Yes & Yes & Yes \\
\hline Industry fixed effects & Yes & Yes & Yes & Yes \\
\hline qFamily & $-0.005(0.015)$ & & $-0.014(0.015)$ & \\
\hline Fboard & $-0.018(0.013)$ & & $-0.015(0.015)$ & \\
\hline DAP*Size & $0.021(0.010)^{* *}$ & $0.023(0.010) *$ & $0.020(0.010) * *$ & $0.027(0.011) *$ \\
\hline DAP*Founder & $-0.006(0.015)$ & $-0.015(0.018)$ & $-0.014(0.016)$ & $-0.006(0.016)$ \\
\hline DAP*qFamily & $-0.004(0.009)$ & & $-0.004(0.009)$ & \\
\hline DAP*Fboard & $0.003(0.007)$ & & $0.001(0.009)$ & \\
\hline $\mathrm{R}^{2}$ & 0.36 & 0.29 & 0.38 & 0.28 \\
\hline Obs & 808 & 665 & 737 & 777 \\
\hline
\end{tabular}

*** Indicate significance at the $1 \%$ level; ${ }^{* *}$ Indicate significance at the $5 \%$ level; ${ }^{*}$ Indicate significance at the $10 \%$ level. 


\section{Discussion}

The literature provides evidence of firms' attitudes in using CSR disclosure in order to gain and/or preserve organizational legitimacy, both in family and non-family businesses. This study has addressed the issue of CSR disclosure as a means of defending a firm's legitimacy in the presence of earnings management practices. Our findings point out differences in behavior between family and non-family firms, and within family businesses. In line with previous studies on earnings management practices [23], we found that family firms are less prone than their non-family counterparts to engage either in managing earnings downward or upward, as these practices may harm family business stakeholders. Consistent with Hypothesis 1, our findings show that family firms are particularly committed to diverting attention from earnings adulterated reductions and, in the presence of this practice, they increase their CSR disclosure, in order to convey an ethical image. As a matter of fact, family firms are characterized by proactive stakeholder engagement [62] and this enhances the level of their stakeholders' confidence in CSR communication [25]. The cost/benefit trade-off of CSR disclosure is likely to be lower in family than non-family firms, and family firms are more prone to using this type of information as an effective signal to maintain stakeholders' trust. A firm may manage earnings downward, in order to retain resources within it. In so doing, they avoid the use of external capital, which may put family control at risk, and, at the same time, they may set aside resources, looking long-term, to ensure business succession for future generations. This practice is detrimental to a number of family stakeholders, in primis, non-family shareholders and the state, notably via dividend and taxation reduction. If it is discovered, it causes significant damage to the firm and the family. The former would suffer a loss of organizational legitimacy, and would be perceived as a bad citizen - harming the firm's survival-and the owning family would suffer reputational damage, due to the strong sense of identification between the family and the business [59]. Due to this close identification, families are very sensitive about their company reputation among external stakeholders; they behave in a way that improves the firm's external image [102]. Family firms may use social and environmental information in order to build an ethical image towards these types of stakeholders and be perceived as good corporate citizens [103]. As a matter of fact, the state takes care of a firm's commitment to sustainable behavior, and the same is true for minority shareholders, who may prefer to invest in socially and environmentally-sensitive businesses for ethical, as well as economic, motivations $[104,105]$.

Firms that manage earnings downward also damage non-family employees in the presence of earnings-based remuneration. Therefore, family firms, given the strong relation with employees who belong to a sort of extended family [39], tend to avoid this practice. When family businesses resort to it, they tend to mask this behavior, transmitting a trusty image, in order to facilitate a long-term relationship with employees, who are likely to positively value being part of a sustainable business.

Consistent with Hypothesis 2, our results highlight that family firms' engagement in masking downward earnings management increases in line with firm size, due to the inflating effect of visibility on potential reputational damage and consequent loss of socioemotional wealth, and this effect is not significant for non-family firms. Within family firms, the propensity to disguise earnings manipulation by means of CSR disclosure seems to be more related to dimensional rather than qualitative characteristics, such as the presence of the founder or of family members on the board. The absence of a significant effect of the founder on the relationship under study does not mean that reputational concerns are lower in the presence of the founder but, in accordance with previous studies on earnings management in family firms, it is likely to be due to the beneficial effect of the founder on earnings quality [52], related to the stronger motivation for socioemotional wealth preservation [23]. The absence of a significant effect of family board members on the relationship between earnings management and CSR disclosure may be due to the opposite effect they have in different generational stages. In the early generational stages, the socioemotional wealth and the reputational concerns are higher, due to the effects of the founder on family members and the strong sense of identification between the family and the business. In later generational stages, the presence of family members 
belonging to different family branches, often conflicting, weakens the socioemotional wealth and the concerns for a firm's image [106]. Regardless, the presence of the founder and the direct influence of family members on the board do not affect the relationship between CSR disclosure and earnings management, but this evidence does not imply that governance mechanisms are not relevant. Other mechanisms may be related. The pressure of market competition, by affecting managerial slacks [107], may influence earnings management practices and camouflage attitudes. Moreover, companies differently use equity incentives, as they set their optimal levels [108], and this compensation structure, via its influence on executives' risk-taking behaviors [109], may influence earnings management practices and the effect on CSR disclosure. Similarly, in the presence of significant external tournament incentives, managers may act in order to win the tournament prize [99] and be more prone to resorting to EM and to diverting attention from this practice. An opposite effect may stem from an effective mutual monitoring among executives, as it may prevent unethical behaviors [110] and, of consequence, it may reduce the use of CSR disclosure for masking EM.

The relationship between downward earnings management and CSR disclosure extent significantly increases with a firm's size- on the one hand, because the reputational threat is stronger for more visible companies and, on the other hand, because larger businesses have a better ability to absorb the cost of a CSR engagement signal via reporting. Family ownership has a moderating effect on the relationship between downward earnings management and the extent of CSR disclosure. When the level of family ownership increases, minority shareholder pressure lessens and, in turn, the need to divert attention from this type of earnings management, and the power of the signal used to convey an ethical image, decreases. As a matter of fact, firms receive legitimacy from different stakeholder groups, depending on how they ensure the achievement of their goals. Empirical findings on family firms' social and environmental disclosure [22,111] suggest that firms that obtain a high degree of legitimacy from internal stakeholders are less likely to engage in CSR disclosure in order to maintain or increase external stakeholder legitimacy. In family firms, internal stakeholder legitimacy rises in line with family ownership stake and, consequently, family control and influence. Further, family ownership extent may moderate the use of CSR disclosure as a tool for maintaining legitimacy.

Our findings suggest a lower engagement in masking upward earnings management by means of CSR disclosure, as we found a positive significant relationship only for larger family firms that are more visible and could potentially suffer high reputational damage. Previous studies have highlighted that inflating earnings practices in family firms is driven by the need to facilitate debt management [28]. The less significant relationship between upward earnings management and the extent of CSR suggests that family firms view this type of information as being of less interest for their lenders [112]: they may rely on other signals that are more focused on voluntary financial disclosure, such as earnings forecasts.

Conversely, although non-family firms are more prone to engaging in earnings management, our results highlight that they do not seem to resort to CSR to camouflage motivations. Moreover, these findings suggest a positive relationship between earnings quality and CSR disclosure in non-family firms, as pointed out by the significant negative relationship between upward earnings management and CSR disclosure.

All in all, the evidence that family firms are more prone to using CSR disclosure to divert attention from earnings management-although they are less willing to resort to this practice-supports recent theoretical contributions pointing out the self-interested nature of socioemotional wealth [113]. According to this view, socioemotional wealth is a selfish objective, whose beneficial effects for stakeholders are merely incidental; therefore, there is a need for family firms to move away from this restricted view of SEW, toward a broader view of SEW [114]. This would directly take into account the interest of stakeholders, in order to ensure their support for a firm's long-term durability.

\section{Conclusions}

This paper focuses on the relationship between earnings management and CSR disclosure in family firms and, by analyzing a sample of 226 Italian listed companies for the period, 2006-2015, 
reveals a difference in the relationship between earnings management and the extent of CSR disclosure in family and non-family firms. The findings suggest that family firms, given their strong concern for family reputation and the preservation of socioemotional wealth, are likely to use CSR disclosure in order to mask downward earnings management, which may directly damage important stakeholders, such as employees, minority shareholders and the state. These results have practical implications, as they highlight that family firms' engagement in social and environmental reporting cannot be seen as an indicator of the good quality of financial information. Conversely, family firms are unlikely to use social and environmental disclosure, in order to divert attention from upward earnings management. This evidence opens the door for further research, as it would be of interest to analyze whether family firms use other signals to shift attention away from this behavior or if they perceive it as being indirectly potentially harmful to their stakeholders and, therefore, are less concerned with the effect on reputation. This exploratory study focused on the differences between family and non-family firms in the relation between earnings management and CSR disclosure, drawing on the SEW preservation motivation. This analysis presents some limitations. The first is that it takes into account only the main SEW dimension (i.e., family control and influence) on the relationship between earnings management and the extent of CSR disclosure. Further studies could analyze the differences within family firms in greater depth, taking into account the effects of the different SEW dimensions on this relationship, also controlling for the generational stage. A second limitation is that this study was single-country focused; future research might address this issue in an international setting, in order to explore the effect of different institutional contexts. A third limitation is that we took in consideration a limited number of governance variables, but the effect of other governance mechanisms related to management incentives and monitoring, or market competition, should be addressed. Moreover, we focused on a sample of publicly-traded firms and listing is a form of visibility, which may enhance family firms' reputational concern. Therefore, it may also be of interest to analyze the behavior of private firms.

Acknowledgments: The authors are grateful to the Editor and to the anonymous reviewers for their valuable comments. Author Contributions: Giovanna Gavana, Pietro Gottardo and Anna Maria Moisello conceived and designed the study; Giovanna Gavana, Pietro Gottardo and Anna Maria Moisello constructed the database and analyzed the data; Giovanna Gavana, Pietro Gottardo and Anna Maria Moisello contributed analyses tools; Giovanna Gavana, Pietro Gottardo and Anna Maria Moisello wrote the paper.

Conflicts of Interest: The authors declare no conflict of interest.

\section{References}

1. Haniffa, R.M.; Cooke, T.E. The impact of culture and governance on corporate social reporting. J. Account. Public Policy 2005, 24, 391-430. [CrossRef]

2. Sethi, S.P. A conceptual framework for environmental analysis of social issues and evaluation of business response patterns. Acad. Manag. Rev. 1979, 4, 63-74.

3. Oliver, C. Strategic responses to institutional processes. Acad. Manag. Rev. 1991, 16, 145-179. [CrossRef]

4. Scott, W.R. The adolescence of institutional theory. Admin. Sci. Q. 1987, 32, 493-511. [CrossRef]

5. Suchman, M.C. Managing legitimacy: Strategic and institutional approaches. Acad. Manag. Rev. 1995, 20, 571-610.

6. Lindblom, C.K. The implications of organizational legitimacy for corporate social performance and disclosure. In Social and Environmental Accounting Volume Developing the Field; Gray, R., Bebbington, J., Gray, S., Eds.; Sage: London, UK, 2010.

7. Dowling, J.; Pfeffer, J. Organizational legitimacy: Social values and organizational behavior. Pac. Sociol. Rev. 1975, 18, 122-136. [CrossRef]

8. Deegan, C. Introduction: The legitimizing effect of social and environmental disclosures-A theoretical foundation. Account. Audit. Account. J. 2002, 15, 282-311. [CrossRef]

9. Chih, H.L.; Shen, C.H.; Kang, F.C. Corporate social responsibility, investor protection, and earnings management: Some international evidence. J. Bus. Ethics 2008, 79, 179-198. [CrossRef] 
10. Salewski, M.; Zülch, H. The Association between Corporate Social Responsibility (CSR) and Earnings Quality-Evidence from European Blue Chips. 2014. HHL Working Paper No. 112. Available online: https: / ssrn.com/abstract=2141768 (accessed on 10 August 2017).

11. Hooghiemstra, R. Corporate communication and impression management: New perspective why companies engage in Corporate Social Reporting. J. Bus. Ethics 2000, 27, 55-68. [CrossRef]

12. Bebbington, J.; Larrinaga, C.; Moneva, J.M. Corporate social reporting and reputation risk management. Account. Audit. Account. J. 2008, 21, 337-361. [CrossRef]

13. Martínez-Ferrero, J.; Garcia-Sanchez, I.M.; Cuadrado-Ballesteros, B. Effect of financial reporting quality on sustainability information disclosure. Corp. Soc. Responsib. Environ. Manag. 2015, 22, 45-64. [CrossRef]

14. Anderson, J.C.; Frankle, A.W. Voluntary social reporting: An iso-beta portfolio analysis. Account. Rev. 1980, $55,467-479$.

15. Dhaliwal, D.; Li, O.Z.; Tsang, A.; Yang, Y.G. Corporate social responsibility disclosure and the cost of equity capital: The roles of stakeholder orientation and financial transparency. J. Account. Public Policy 2014, 33, 328-355. [CrossRef]

16. Prior, D.; Surroca, J.; Tribó, J.A. Are socially responsible managers really ethical? Exploring the relationship between earnings management and corporate social responsibility. Corp. Gov. Int. Rev. 2008, 16, 160-177. [CrossRef]

17. Scholtens, B.; Kang, F.C. Corporate social responsibility and earnings management: Evidence from Asian economies. Corp. Soc. Responsib. Environ. Manag. 2013, 20, 95-112. [CrossRef]

18. Patten, D.M.; Trompeter, G. Corporate responses to political costs: An examination of the relation between environmental disclosure and earnings management. J. Account. Public Policy 2003, 22, 83-94. [CrossRef]

19. Yip, E.; Van Staden, C.; Cahan, S. Corporate social responsibility reporting and earnings management: The role of political costs. Australas. Account. Bus. Financ. J. 2011, 5, 17-34.

20. Sun, N.; Salama, A.; Hussainey, K.; Habbash, M. Corporate environmental disclosure, corporate governance and earnings management. Manag. Audit. J. 2010, 25, 679-700. [CrossRef]

21. Campopiano, G.; De Massis, A. Corporate social responsibility reporting: A content analysis in family and non-family firms. J. Bus. Ethics 2010, 129, 511-534. [CrossRef]

22. Gavana, G.; Gottardo, P.; Moisello, A.M. Sustainability Reporting in Family Firms: A Panel Data Analysis. Sustainability 2017, 9, 38. [CrossRef]

23. Martin, G.; Campbell, J.T.; Gomez-Mejia, L. Family control, socioemotional wealth and earnings management in publicly traded firms. J. Bus. Ethics 2016, 133, 453-469. [CrossRef]

24. Achleitner, A.K.; Günther, N.; Kaserer, C.; Siciliano, G. Real earnings management and accrual-based earnings management in family firms. Eur. Account. Rev. 2014, 23, 431-461. [CrossRef]

25. Nekhili, M.; Nagati, H.; Chtioui, T.; Rebolledo, C. Corporate social responsibility disclosure and market value: Family versus nonfamily firms. J. Bus. Res. 2017, 77, 41-52. [CrossRef]

26. Cahan, S.F.; De Villiers, C.; Jeter, D.C.; Naiker, V.; Van Staden, C.J. Are CSR disclosures value relevant? Cross-country evidence. Eur. Account. Rev. 2016, 25, 579-611. [CrossRef]

27. Van der Laan Smith, J.; Adhikari, A.; Tondkar, R.H. Exploring differences in social disclosures internationally: A stakeholder perspective. J. Account. Public Policy 2005, 24, 123-151. [CrossRef]

28. Prencipe, A.; Markarian, G.; Pozza, L. Earnings management in family firms: Evidence from R\&D cost capitalization in Italy. Fam. Bus. Rev. 2008, 21, 71-88.

29. Corbetta, G.; Minichilli, A. Il governo delle imprese italiane quotate a controllo familiare: I risultati di una ricerca esplorativa. Econ. Manag. 2005, 6, 59-77.

30. Gomez-Mejia, L.R.; Cruz, C.; Berrone, P.; De Castro, J. The bind that ties: Socioemotional wealth preservation in family firms. Acad. Manag. Ann. 2011, 5, 653-707. [CrossRef]

31. Brown, N.; Deegan, C. The public disclosure of environmental performance information-a dual test of media agenda setting theory and legitimacy theory. Account. Bus. Res. 1998, 29, 21-41.

32. Scott, W.R.; Christensen, S. The Institutional Construction of Organizations: International and Longitudinal Studies; Sage Publications, Inc.: Thousand Oaks, CA, USA, 1995.

33. Certo, S.T. Influencing initial public offering investors with prestige: Signaling with board structures. Acad. Manag. Rev. 2003, 28, 432-446.

34. Banerjee, S.B. Corporate environmentalism: The construct and its measurement. J. Bus. Res. 2002, 55, $177-191$. [CrossRef] 
35. Bird, R.B.; Smith, E.A. Signaling theory, strategic interaction, and symbolic capital. Curr. Anthropol. 2005, 46, 221-248. [CrossRef]

36. Pazzaglia, F.; Mengoli, S.; Sapienza, E. Earnings quality in acquired and nonacquired family firms: A socioemotional wealth perspective. Fam. Bus. Rev. 2013, 26, 374-386. [CrossRef]

37. Stockmans, A.; Lybaert, N.; Voordeckers, W. Socioemotional wealth and earnings management in private family firms. Fam. Bus. Rev. 2010, 23, 280-294. [CrossRef]

38. Gómez-Mejia, L.R.; Haynes, K.T.; Núñez-Nickel, M.; Jacobson, K.J.; Moyano-Fuentes, J. Socioemotional wealth and business risks in family-controlled firms: Evidence from Spanish olive oil mills. Admin. Sci. $Q$. 2007, 52, 106-137. [CrossRef]

39. Berrone, P.; Cruz, C.; Gomez-Mejia, L.R. Socioemotional wealth in family firms: Theoretical dimensions, assessment approaches, and agenda for future research. Fam. Bus. Rev. 2012, 25, 258-279. [CrossRef]

40. Cruz, C.; Justo, R.; De Castro, J.O. Does family employment enhance MSEs performance? Integrating socioemotional wealth and family embeddedness perspectives. J. Bus. Ventur. 2012, 27, 62-76. [CrossRef]

41. Kepner, E. The family and the firm: A evolutionary perspective. Organ. Dyn. 1983, 12, 57-70. [CrossRef]

42. Brammer, S.; Pavelin, S. Voluntary social disclosures by large UK companies. Bus. Ethics Eur. Rev. 2004, 13, 86-99. [CrossRef]

43. Branco, M.C.; Rodrigues, L.L. Factors influencing social responsibility disclosure by Portuguese companies. J. Bus. Ethics 2008, 83, 685-701. [CrossRef]

44. Block, J.; Stiglbauer, M.; Kühn, A.L.; Wagner, K. Corporate social responsibility communication of German family firms: A content analysis. uwf UmweltWirtschaftsForum 2015, 23, 251-257. [CrossRef]

45. Cuadrado-Ballesteros, B.; Rodríguez-Ariza, L.; García-Sánchez, I.M. The role of independent directors at family firms in relation to corporate social responsibility disclosures. Int. Bus. Rev. 2015, 24, 890-901. [CrossRef]

46. Ali, A.; Chen, T.Y.; Radhakrishnan, S. Corporate disclosures by family firms. J. Account. Econ. 2007, 44, 238-286. [CrossRef]

47. Fan, J.P.; Wong, T.J. Corporate ownership structure and the informativeness of accounting earnings in East Asia. J. Account. Econ. 2002, 33, 401-425. [CrossRef]

48. Kim, J.B.; Yi, C.H. Ownership structure, business group affiliation, listing status, and earnings management: Evidence from Korea. Contemp. Account. Res. 2006, 23, 427-464. [CrossRef]

49. Chen, K.Y.; Elder, R.J.; Hsieh, Y.M. Corporate governance and earnings management: The implications of corporate governance best-practice principles for Taiwanese listed companies. J. Contemp. Account. Econ. 2007, 3, 73-105. [CrossRef]

50. Stein, J.C. Takeover threats and managerial myopia. J. Political Econ. 1988, 96, 61-80. [CrossRef]

51. Stein, J.C. Efficient capital markets, inefficient firms: A model of myopic corporate behavior. Q. J. Econ. 1989, 104, 655-669. [CrossRef]

52. Wang, D. Founding family ownership and earnings quality. J. Account. Res. 2006, 44, 619-656. [CrossRef]

53. Yang, M.L. The impact of controlling families and family CEOs on earnings management. Fam. Bus. Rev. 2010, 23, 266-279. [CrossRef]

54. Jaggi, B.; Leung, S.; Gul, F. Family control, board independence and earnings management: Evidence based on Hong Kong firms. J. Account. Public Policy 2009, 28, 281-300. [CrossRef]

55. Prencipe, A.; Bar-Yosef, S. Corporate governance and earnings management in family-controlled companies. J. Account. Audit. Financ. 2011, 26, 199-227. [CrossRef]

56. Chi, C.W.; Hung, K.; Cheng, H.W.; Lieu, P.T. Family firms and earnings management in Taiwan: Influence of corporate governance. Int. Rev. Econ. Financ. 2015, 36, 88-98. [CrossRef]

57. Deephouse, D.L.; Jaskiewicz, P. Do family firms have better reputations than non-family firms? An integration of socioemotional wealth and social identity theories. J. Manag. Stud. 2013, 50, 337-360. [CrossRef]

58. Dyer, W.G.; Whetten, D.A. Family firms and social responsibility: Preliminary evidence from the S\&P 500. Entrep. Theory Pract. 2006, 30, 785-802.

59. Berrone, P.; Cruz, C.; Gomez-Mejia, L.R.; Larraza-Kintana, M. Socioemotional wealth and corporate responses to institutional pressures: Do family-controlled firms pollute less? Admin. Sci. Q. 2010, 55, 82-113. [CrossRef]

60. Dacin, M.T.; Oliver, C.; Roy, J.P. The legitimacy of strategic alliances: An institutional perspective. Strateg. Manag. J. 2007, 28, 169-187. [CrossRef] 
61. Fisher, J.; Gunz, S.; McCutcheon, J. Private/public interest and the enforcement of a code of professional conduct. J. Bus. Ethics 2001, 31, 191-207. [CrossRef]

62. Cennamo, C.; Berrone, P.; Cruz, C.; Gomez-Mejia, L.R. Socioemotional wealth and proactive stakeholder engagement: Why family controlled firms care more about their stakeholders? Entrep. Theory Pract. 2012, 36, 1153-1173. [CrossRef]

63. Brammer, S.; Pavelin, S. Factors influencing the quality of corporate environmental disclosure. Bus. Strateg. Environ. 2008, 17, 120-136. [CrossRef]

64. Dyduch, J.; Krasodomska, J. Determinants of Corporate Social Responsibility Disclosure: An Empirical Study of Polish Listed Companies. Sustainability 2017, 9, 1934. [CrossRef]

65. Reverte, C. Determinants of corporate social responsibility disclosure ratings by Spanish listed firms. J. Bus. Ethics 2009, 88, 351-366. [CrossRef]

66. Morhardt, J.E. Corporate social responsibility and sustainability reporting on the internet. Bus. Strateg. Environ. 2010, 19, 436-452. [CrossRef]

67. Lu, F.; Kozak, R.; Toppinen, A.; D’Amato, D.; Wen, Z. Factors Influencing Levels of CSR Disclosure by Forestry Companies in China. Sustainability 2017, 9, 1800. [CrossRef]

68. Godfrey, P.C. The relationship between corporate philanthropy and shareholder wealth: A risk management perspective. Acad. Manag. Rev. 2005, 30, 777-798. [CrossRef]

69. Zellweger, T.M.; Nason, R.S.; Nordqvist, M.; Brush, C.G. Why do family firms strive for nonfinancial goals? An organizational identity perspective. Entrep. Theory Pract. 2013, 37, 229-248. [CrossRef]

70. Hernández-Perlines, F.; Rung-Hoch, N. Sustainable entrepreneurial orientation in family firms. Sustainability 2017, 9, 1212. [CrossRef]

71. Cooke, T.E. The impact of size, stock market listing and industry type on disclosure in the annual reports of Japanese listed corporations. Account. Bus. Res. 1992, 22, 229-237. [CrossRef]

72. Villalonga, B.; Amit, R. Family control of firms and industries. Financ. Manag. 2010, 39, 863-904. [CrossRef]

73. Zeng, S.X.; Xu, X.D.; Yin, H.T.; Tam, C.M. Factors that drive Chinese listed companies in voluntary disclosure of environmental information. J. Bus. Ethics 2012, 109, 309-321. [CrossRef]

74. Cormier, D.; Gordon, I.M.; Magnan, M. Corporate environmental disclosure: Contrasting management's perceptions with reality. J. Bus. Ethics 2004, 49, 143-165. [CrossRef]

75. Dang, C.; Li, Z.C.; Yang, C. Measuring firm size in empirical corporate finance. J. Bank. Financ. 2018, 86, 159-176. [CrossRef]

76. Tagesson, T.; Blank, V.; Broberg, P.; Collin, S.O. What explains the extent and content of social and environmental disclosures on corporate websites: A study of social and environmental reporting in Swedish listed corporations. Corp. Soc. Responsib. Environ. Manag. 2009, 16, 352-364. [CrossRef]

77. Khan, M.H.U.Z. The effect of corporate governance elements on corporate social responsibility (CSR) reporting: Empirical evidence from private commercial banks of Bangladesh. Int. J. Law Manag. 2010, 52, 82-109. [CrossRef]

78. Gamerschlag, R.; Möller, K.; Verbeeten, F. Determinants of voluntary CSR disclosure: Empirical evidence from Germany. Rev. Manag. Sci. 2011, 5, 233-262. [CrossRef]

79. Rahman, N.H.W.A.; Zain, M.M.; Al-Haj, N.H.Y.Y. CSR disclosures and its determinants: Evidence from Malaysian government link companies. Soc. Responsib. J. 2011, 7, 181-201. [CrossRef]

80. Siregar, S.V.; Bachtiar, Y. Corporate social reporting: Empirical evidence from Indonesia Stock Exchange. Int. J. Islam. Middle East. Financ. Manag. 2010, 3, 241-252. [CrossRef]

81. Stavrou, E.; Kassinis, G.; Filotheou, A. Downsizing and Stakeholder Orientation Among the Fortune 500: Does Family Ownership Matter? J. Bus. Ethics 2007, 72, 149-162. [CrossRef]

82. García-Álvarez, E.; López-Sintas, J. A taxonomy of founders based on values: The root of family business heterogeneity. Fam. Bus. Rev. 2001, 14, 209-230. [CrossRef]

83. Chua, J.H.; Chrisman, J.J.; Steier, L.P.; Rau, S.B. Sources of heterogeneity in family firms: An introduction. Entrep. Theory Pract. 2012, 36, 1103-1113. [CrossRef]

84. Dechow, P.M.; Sloan, R.G.; Sweeney, A.P. Detecting earnings management. Account. Rev. 1995, 70, $193-225$.

85. Bartov, E.; Gul, F.A.; Tsui, J.S. Discretionary-accruals models and audit qualifications. J. Account. Econ. 2000, 30, 421-452. [CrossRef]

86. Peasnell, K.V.; Pope, P.F.; Young, S. Detecting earnings management using cross-sectional abnormal accruals models. Account. Bus. Res. 2000, 30, 313-326. [CrossRef] 
87. Subramanyam, K.R. The pricing of discretionary accruals. J. Account. Econ. 1996, 22, 249-281. [CrossRef]

88. Healy, P.M. The effect of bonus schemes on accounting decisions. J. Account. Econ. 1985, 7, 85-107. [CrossRef]

89. Jones, J.J. Earnings management during import relief investigations. J. Account. Res. 1991, 29, $193-228$. [CrossRef]

90. Li, F. Endogeneity in CEO power: A survey and experiment. Invest. Anal. J. 2016, 45, 149-162. [CrossRef]

91. Ang, A.; Bekaert, G. Stock return predictability: Is it there? Rev. Financ. Stud. 2007, 20, 651-707. [CrossRef]

92. Palia, D. The endogeneity of managerial compensation in firm valuation: A solution. Rev. Financ. Stud. 2001, 14, 735-764. [CrossRef]

93. Dittmar, A.; Mahrt-Smith, J. Corporate governance and the value of cash holdings. J. Financ. Econ. 2007, 83, 599-634. [CrossRef]

94. Faleye, O. Classified boards, firm value, and managerial entrenchment. J. Financ. Econ. 2007, 83, 501-529. [CrossRef]

95. Bennedsen, M.; Nielsen, K.M.; Pérez-González, F.; Wolfenzon, D. Inside the family firm: The role of families in succession decisions and performance. Q. J. Econ. 2007, 122, 647-691. [CrossRef]

96. Laeven, L.; Levine, R. Bank governance, regulation and risk taking. J. Financ. Econ. 2009, 93, $259-275$. [CrossRef]

97. Linck, J.S.; Netter, J.M.; Yang, T. The determinants of board structure. J. Financ. Econ. 2008, 87, 308-328. [CrossRef]

98. Gatchev, V.A.; Pulvino, T.; Tarhan, V. The interdependent and intertemporal nature of financial decisions: An application to cash flow sensitivities. J. Financ. 2010, 65, 725-763. [CrossRef]

99. Coles, J.L.; Li, Z.F.; Wang, Y.A. Industry tournament incentives. Rev. Financ. Stud. 2018, in press.

100. Huang, R.; Ritter, J.R. Testing theories of capital structure and estimating the speed of adjustment. J. Financ. Quant. Anal. 2009, 44, 237-271. [CrossRef]

101. Anderson, R.C.; Reeb, D.M. Founding-family ownership and firm performance: Evidence from the S\&P 500. J. Financ. 2003, 58, 1301-1328.

102. Micelotta, E.R.; Raynard, M. Concealing or revealing the family? Corporate brand identity strategies in family firms. Fam. Bus. Rev. 2011, 24, 197-216. [CrossRef]

103. Neu, D.; Warsame, H.; Pedwell, K. Managing public impressions: Environmental disclosures in annual reports. Account. Org. Soc. 1998, 23, 265-282. [CrossRef]

104. Murray, A.; Sinclair, D.; Power, D.; Gray, R. Do financial markets care about social and environmental disclosure? Further evidence and exploration from the UK. Acc. Audit. Account. J. 2006, 19, 228-255. [CrossRef]

105. Cohen, J.R.; Holder-Webb, L.; Zamora, V.L. Nonfinancial Information Preferences of Professional Investors. Behav. Res. Account. 2015, 27, 127-153. [CrossRef]

106. Le Breton-Miller, I.; Miller, D.; Lester, R.H. Stewardship or agency? A social embeddedness reconciliation of conduct and performance in public family businesses. Organ. Sci. 2011, 22, 704-721. [CrossRef]

107. Giroud, X.; Mueller, H.M. Corporate governance, product market competition, and equity prices. J. Financ. 2011, 66, 563-600. [CrossRef]

108. Core, J.; Guay, W. The use of equity grants to manage optimal equity incentive levels. J. Account. Econ. 1999, 28, 151-184. [CrossRef]

109. Coles, J.L.; Daniel, N.D.; Naveen, L. Managerial incentives and risk-taking. J. Financ. Econ. 2006, 79, 431-468. [CrossRef]

110. Li, Z.F. Mutual monitoring and corporate governance. J. Bank. Financ. 2014, 45, 255-269.

111. Cabeza-Garcia, L.; Sacristàn-Navarro, M.; Gòmez-Ansòn, S. Family involvement and corporate social responsibility disclosure. J. Fam. Bus. Strategy 2017, 8, 109-122. [CrossRef]

112. Gavana, G.; Gottardo, P.; Moisello, A.M. The effect of equity and bond issues on sustainability disclosure. Family vs. non-family Italian firms. Soc. Responsib. J. 2017, 13, 126-142. [CrossRef]

113. Newbert, S.; Craig, J.B. Moving beyond Socioemotional Wealth: Toward a Normative Theory of Decision Making in Family Business. Fam. Bus. Rev. 2017, 30, 339-346. [CrossRef]

114. Miller, D.; Breton-Miller, L. Deconstructing socioemotional wealth. Entrep. Theory Pract. 2014, 38, 713-720. [CrossRef] 
(C) 2017 by the authors. Licensee MDPI, Basel, Switzerland. This article is an open access article distributed under the terms and conditions of the Creative Commons Attribution (CC BY) license (http:/ / creativecommons.org/licenses/by/4.0/). 